EISSN: 2706 -7947 ISSN: 2077- 4613

DOI: 10.36632/mejas/2021.11.2.38

Journal homepage: www.curresweb.com

Pages: 461-471

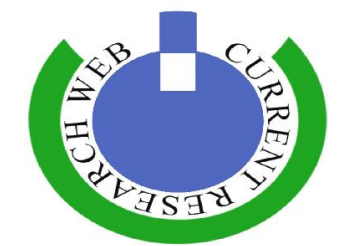

\title{
Effect of Gamma Irradiation on flowering Characters and aspects in anatomical structure of Helichrysum bracteatum $\mathrm{L}$.
}

\author{
Rawia A. Eid ${ }^{1}$, Hashish Kh. ${ }^{1}$, M.A. El-Khateeb ${ }^{2}$, H.A. Ashour ${ }^{2}$ and R.M.S. Radwan ${ }^{1}$
}

${ }^{I}$ Department of Ornamental Plants and Woody Trees, Agricultural \& Biological Research Division, National Research Centre (NRC), 33 El-Buhouth St., 12622 Dokki, Giza, Egypt.

${ }^{2}$ Department of Ornamental Horticulture, Faculty of Agriculture, Cairo University, Giza, Egypt.

\author{
Received: 25 March $2021 \quad$ Accepted: 10 May Published: 15 May 2021
}

\begin{abstract}
Two experiment were carried out on Helichrysum bracteatum L. plant at the Experimental nursery of the Ornamental Hort. Dept., Fac. Agric., Cairo Univ., Giza, Egypt, during the two successive seasons (2014/15and 2015/16). The aim of this study was to investigate the effect of gamma irradiation flowering parameters and anatomical structure of leaves and flowers in two generations (M1and M2).The obtained results showed the following: Seeds of $H$. bracteatum L. were exposed to eight doses of gamma radiation (5- $40 \mathrm{~Gy}$ ). The low doses of gamma radiation increased No. of flowers and flowers diameter per plant in M1 and M2. Were obtained on many morphological variations in flowers color and leaves shape through two generations with doses 15, 20, 25, 30 and $35 \mathrm{~Gy}$. Some flowering parameters and anatomical structure of leaves and flowers and to confirm the stability of some of the mutations were obtained during the second season. The variants of these selections were selection from plants treated with $(15,20,25,30$ and $35 \mathrm{~Gy})$ of gamma rays.
\end{abstract}

Keywords: Gamma, Irradiation, Helichrysum bracteatum L, Flowering characters, Anatomical structure

\section{Introduction}

Helichrysum bracteatum L. is recognized as strawflower or the golden everlasting, it is a blooming plant, belongs to the family Asteraceae. The strawflower, is a flowering plant native to Australia, produces showy flowers with large dark green leaves. Plants can grow to 3-4 feet tall, depending on the variety. The flower is also known as "paper daisy" for its papery texture. Just like the daisy, the center is made up of a cluster of tiny individual flowers. The "petals" surrounding the cluster are actually bracts. The plant flowers or blooms from spring to autumn. The daisy-like flowers come in a wide range of colors, including yellow, orange, pink, deep rose, red, wine, magneto, purple and white blooms. It was known as Helichrysum bracteatum for many years before being transferred to a new genus Xerochrysum in 1990. Helichrysum are producing worldwide as fresh and dried flowers. The flowers are harvested for drying before fully opening and used in dried arrangements (Sharman et al. (1989 a,b) and Nishikawa et al. (2008).

Gamma irradiation is one of the main physical mutagens for mutation studies in plants. It has adverse effect on traits of plants and this depended on plant species or varieties and the dose of irradiation (Artk and Peksen 2006). Mutagenesis by means of gamma rays plays an important role in the producing new mutants with improved properties, which can produce higher amounts of commercially important metabolites

This study was conducted to investigate the response of Helichrysum bracteatum L. to gamma radiation to evaluate the effects of gamma irradiation on quantitative and qualitative traits of growth and flowering photosynthetic pigments and anatomical structure of leaves and flowers. 


\section{Materials and Methods}

A field experiment was conducted during the two successive seasons of 2014/15 and 2015/16 at Experimental Station, Faculty of Agriculture, Cairo University, Egypt.

The seeds of H. bracteatum L. (Local variety) were obtained from Ornamental Horticultural Department, Faculty of Agriculture, Cairo University, Egypt. This study for two generations (M1 andM2) of 2014/2015and 2015/2016 were irradiated using gamma rays at Atomic Energy Commission-united irradiation -Gamma, Nasr city, Egypt. at doses of 0, 5, 10, 15, 20, 30, 35 and 40 Gy and seeds of the control were kept without irradiation, using gamma-1type 137 gamma, cesium 137, dose rate $=0.751 \mathrm{rad} / \mathrm{Sec}$. Gray $2: 13 \mathrm{~min} / \mathrm{sec}$. Plants of the M1-plants, which survived in each treatment, were selected and selfed, in order to obtain for M1and M2 generations, respectively), according to Sinhamahapatra and Rakshit (1990).

\subsection{Preparing seedlings and transplantation}

Gamma rays radiation experiment: batches of 1000 seeds were treated with one dose of gammairradiation $\left(0.0,5,10,15,20,25,30,35\right.$ and 40 Gy). On $5^{\text {th }}$ Nov., 2014; $5^{\text {th }}$ Nov., 2015 and $5^{\text {th }}$ Nov., 2016 (for M1and M2 generations, respectively) the treated seeds of both experiments (gamma rays) were sown in plastic trays, filled with a mixture of peat moss, sand and loam $(2: 1: 1)$ by volume. Seed germination was started after one week of sowing. Six weeks after sowing $\left(16^{\text {th }}\right.$ Dec., $2014 ; 16^{\text {th }}$ Dec., 2015 and $16^{\text {th }}$ Dec., 2016, for M1and M2 generations, respectively), uniform seedlings $(10-12 \mathrm{~cm}$ height) of $H$. bracteatum L. of each treatment were transplanted into hills, in open field of experimental area (clay loam soil), in three rows at $60 \mathrm{~cm}$ apart, at $50 \mathrm{~cm}$ between the hills within the 65 row (two plants/hill), as every plot $(3.5 \times 1.8 \mathrm{~m})$ contained 21 hills /plot.

\subsection{Soil analysis}

Soil analysis indicated that, particle size distribution (\%) was: sand: 26.8 , silt: 26.1 and clay: 37.1 (texture: clay loam), pH: 7.9, EC ds.m-1: 0.95 , soluble cations (meq./1) were $\mathrm{Na}^{+}: 0.71, \mathrm{~K}^{+}: 0.4, \mathrm{Ca}^{++}: 1.3$, $\mathrm{Mg}^{++}: 0.9$ and soluble anions (meq./1) were $\mathrm{Cl}: 1.5, \mathrm{HCO}_{3}: 0.75, \mathrm{CO}_{3}: 0$ and $\mathrm{SO}_{4}: 1.06$.

\subsection{The first mutative generation (M1)}

The mass selection of plants of M1-generation was run from April to June, 2015, where plants which survived in each treatment, were evaluated, selected and selfed, in order to obtain the second mutative generation (M2) seeds according to Sinhamahapatra and Rakshit (1990). Observations were made throughout the periods of vegetative and flowering. At maturity (June), the seeds of all the survived M1 fertile plants were harvested separately.

\subsection{The second mutative generation (M2)}

The seeds harvested from M1 generation were taken from individual treatments and used to raise M2 generation (seedlings) plants. The M2-generation was done, as seeds were sown on 5th Nov., 2015 in plastic trays, filled with a mixture of peat moss, sand and loam $(2: 1: 1)$ by volume to raise M2 generation plants. The seedlings were transplanted into open field, as in the first generation.

\subsection{Agricultural practices}

All the recommended cultural practices namely, irrigation and weeding were carried out during the plant growth and flowering period.

\subsection{Statistical analysis}

A randomized complete block design with 3 replicates was used. Data of the two experiments were subjected to statistical analysis, according to the procedure of Snedecor and Cochran (1980), where the means separation were carried out using Duncan (1980) multiple range tests and compared using L.S.D test at 0.05 probability levels significance was determined at $\mathrm{P}<0.05$. 


\section{Data recorded}

The following data on vegetative growth, flowering characters (quantitative and qualitative traits) as well as chemical composition, were recorded for plants of M1 and M2 of gamma radiation experiment, plant abnormalities.

The following data were recorded on $H$. bracteatum $\mathrm{L}$. plants grown until the flower opening reached $50 \%$ :
a. Flowering Parameters
1. No. of flowers
2. Flower diameter $(\mathrm{cm})$.
3. Flower stalks length $(\mathrm{cm})$.
4. Fresh weight of flowers per plant (g).
5. Dry weight of flowers per plant (g).

Determination of dry weight: Samples of leaves, stems and flowers were dried in an oven at $70{ }^{\circ} \mathrm{C}$, till a constant weight were obtained (48-72 hours).

\section{b. Plant abnormalities}

\section{c. Anatomical structure of leaves and flowers}

For the anatomical studies of $H$. bracteatum L. plants treated with gamma radiation, samples of plants (leaves and flowers) were fixed and killed for at least 48 hours in F.A.A. (10 ml formalin, $5 \mathrm{ml}$ glacial acetic acid, $50 \mathrm{ml}$ ethyl alcohol $95 \%$, and $35 \mathrm{ml}$ distilled water), washed in $50 \%$ ethanol, dehydrated in normal butyl alcohol series (Sass, 1951) and embedded in paraffin wax. Sections of leaves and flowers were cut to a thickness of 20 microns and stained with safranin light green combination and mounted in Canada balsam, according to (Nassar and El-Sahar, 1998). The slides were microscopically examined. Counts and measurements $(\mu \mathrm{m})$ of the different tissues (leaves and flowers) were taken and calculated using a micrometer eye piece. The surfaces of $H$. bracteatum L. were pictured using light microscope with camera model Leica ICC50 HD at Faculty of Agriculture Research Park, Cairo University.

\section{Results and Discussion}

\subsection{Flowering Parameters}

\subsubsection{Number of flowers /plant}

Data presented in Table (1) showed that the effect of gamma rays at different doses on number of flower per plant. It is obvious that treating plants with the low dose of gamma rays (5 Gy) significantly increased number of flowers per plant to maximum value (24.00) in M1 and (25.33) in M2, while the lowest values of number of flowers were obtained with the treatment of gamma radiation at the dose of $(40 \mathrm{~Gy})$, the decrements in flower production per plant were $(23.08 \%$ in M1 and $21.91 \%$ in M2), respectively compared with the control plants.

The results obtained are in agreement with those obtained by Kainthura and Srivastava (2015) investigated the effect of gamma radiation on floral characters of tuberose (Polianthes tuberosa $\mathrm{L}$ ). They found that lower doses $(0.0,0.5$ and $1.5 \mathrm{Kr})$ had a significant simulative effect on some floral parameters i.e., number of spikes/plant and number of florets/spike; Telem et al. (2015) treated rooted cuttings of chrysanthemum plant with 10,20 and 30 Gy of gamma rays. The results showed that higher dose significantly affected the plant flowering parameters i.e., number of flowers/spray and number of flower/plant.

\subsubsection{Flower diameter (cm)}

The flower diameters as affected by gamma radiation are shown in Table (1). The data indicated that all doses (except $40 \mathrm{~Gy}$ ) of gamma irradiation markedly increased the flower diameter plants. The largest flowers were obtained from the treatment with 20 and $25 \mathrm{~Gy}$, followed by 15 Gy in M1. Numerically, flower diameter $(\mathrm{cm})$ was increased $4.63,4.26$ and $4.2 \mathrm{~cm}$, respectively, in comparison with untreated plants. On the other hand, the smallest flowers $(3.76 \mathrm{~cm})$ occurred by treating seeds with 40 Gy gamma radiation., the data showed inconsistent changes in M2, since these were insignificant 
increase in flowers diameter between doses of gamma radiation and decrease was obtained, particularly at lower and high doses. The significant enhancement was progressively increased with gamma doses from 15 to $30 \mathrm{~Gy}$. The dose $40 \mathrm{~Gy}$ was the lowest value in M2 compared with the other doses.

These results are similar to those found by Telem et al. (2015) irradiated rooted cuttings of chrysanthemum plant with doses 10,20 and 30 Gy of gamma rays. The results showed that the high doses significantly affected the plant flowering parameters and flower diameter. Kumari et al. (2013) on Chrysanthemum morifolium varity "Otome pink". They found that number of flower heads, flower head size and fresh weight were reduced after treating the seeds with doses at $0,10,15$ and $20 \mathrm{~Gy}$, of gamma rays. Oates et al. (2013) on Tetraploid Rudbeckia subtomentosa plant irradiated callus with (0, $5,10,20$ or $40 \mathrm{~Gy}$ ), they observed that diameter of the terminal flowers and diameter of the secondary flowers reduced with increasing radiation dose.

\subsubsection{Flower stalk length (cm)}

It could be observed from data presented in Table (1) that, lower doses of gamma radiation treatments mostly enhanced flower stalk length $(\mathrm{cm})$ at 5 Gy followed by 10,15 and 20 Gy in M1, the highest value of stalk length $(19.32,18.33,19.00$ and $18.13 \mathrm{~cm})$ respectively, in comparison with other treatments of gamma on the control. Whereas in M2 these were significant increases with $5 \mathrm{~Gy}, 10$, and $15 \mathrm{~Gy}$ of gamma treatments where the recorded value were $(18.67,17.70$ and $18.49 \mathrm{~cm})$, respectively, compared with the control plant .Also, gamma dose at 40 Gy resulted the lower values of stalk length in M1 and M2, where it gave the lower values $(11.85$ and $15.01 \mathrm{~cm})$ respectively.

In this concern, the previous results agreed with that obtained by Singh (2014) who concluded that application of gamma rays at the dose of $0.5 \mathrm{Kr}$ on the suckers of nine gerbera varieties had a significantly detrimental effect on flower stalk length, flower duration and number of flowers per plant per year in all varieties studied; Patil (2014) on gladiolus plant studied the effect of gamma radiations by irradiating corms with doses 1, 2, 3, 4, 5, 6 and $7 \mathrm{Kr}$, and stated that higher doses decreased spike length, number and size of florets, while lower doses responded positively.

Also, Dhivya et al. (2015) on crossandra plant treated the seeds with gamma rays at 10, 20, 30, 40 and $50 \mathrm{Kr}$, they found that, number of spikes/plant, number of flowers/spike, length of spike, length of corolla tube, number of flowers/plant and yield per plant increased at lower radiation doses of 10 and $20 \mathrm{Kr}$ than control, and Kainthura and Srivastava (2015) treated corms of Polianthes tuberosa L. with gamma rays at $0.0,0.5$ and $1.5 \mathrm{Kr}$, the results obtained showed decreases in florets/spike with increasing the doses of gamma rays.

\subsubsection{Flowers fresh weight (g/plant)}

As shown in Table (1) treating H. bracteatum plants with the gamma radiation at dose of $5 \mathrm{~Gy}$, insignificantly increased the fresh weight of flowers, in comparison with the control, giving 36.30 $\mathrm{g} / \mathrm{plant}$ in M1 and (49.13 g/plant) in M2. Raising the level of gamma radiation from 5 Gy up to $40 \mathrm{~Gy}$ markedly decreased the average fresh weight of flowers $\mathrm{g} / \mathrm{plant}$ in M1 and M2 (21.59 and $31.92 \mathrm{~g} / \mathrm{plant})$, respectively.

These results are in agreement, to some extent, with those recorded by Kapadiya et al.(2014) on chrysanthemum plant, as flower weight and flower yield/plant were highest at the lowest dose of gamma rays. Also, Kumari et al. (2013) on chrysanthemum plant, stated that flower head size and fresh weight decreased as the dose increased.

\subsubsection{Flower dry weight (g/plant)}

Concerning the effect of gamma rays on flowers dry weight, the obtained data (Table 1), indicted that using gamma rays irradiation at dose of 5 Gy insignificantly increased the flower dry weight compared with the control, giving (15.46 and $17.98 \mathrm{~g} / \mathrm{plant}$ ), respectiely (14.70 and $17.73 \mathrm{~g} / \mathrm{plant}$ ) for control plant in M1 and M2, respectively. On the other hand, the data presented in Table (1) also, indicated that doses of gamma rays up to $15 \mathrm{~Gy}$ gave insignificantly decreased the flower dry weight as compared with the control and treating the seed at $40 \mathrm{~Gy}$ of gamma radiation gave the lowest value of flowers dry weight compared with the control plant. The results revealed that the low dose of gamma 5 Gy increased it, compared with the control. Similar findings were obtained by Kumari et al. (2013) on chrysanthemum plant. 
Table 1: Effect of gamma radiation treatments on Number of flowers /plant, Flower diameter $(\mathrm{cm})$, flower stalk length, flowers fresh weight /plant and flowers dry weight /plant of H. bracteatum L. plant, during the M1 and M2 generations (2014/15 and 2015/16).

\begin{tabular}{|c|c|c|c|c|c|c|c|c|c|c|}
\hline \multirow{2}{*}{$\begin{array}{l}\text { Charact. } \\
\text { Treat. }\end{array}$} & \multicolumn{2}{|c|}{$\begin{array}{c}\begin{array}{c}\text { Number of flowers } \\
\text { /plant }\end{array} \\
\end{array}$} & \multicolumn{2}{|c|}{$\begin{array}{c}\text { Flower diameter } \\
(\mathbf{c m})\end{array}$} & \multicolumn{2}{|c|}{$\begin{array}{c}\text { Flower stalk length } \\
(\mathrm{cm})\end{array}$} & \multicolumn{2}{|c|}{$\begin{array}{c}\text { Flowers fresh weight } \\
(\mathrm{g}) / \text { plant }\end{array}$} & \multicolumn{2}{|c|}{$\begin{array}{c}\text { Flowers dry weight } \\
\text { (g)/plant }\end{array}$} \\
\hline & M1 & M2 & M1 & M2 & M1 & M2 & M1 & M2 & M1 & M2 \\
\hline Control & $21.66 \mathrm{bc}$ & $23.00 \mathrm{~b}$ & $3.83 \mathrm{bc}$ & $3.11 \mathrm{~b}$ & $11.58 \mathrm{f}$ & $15.01 \mathrm{c}$ & $35.26 \mathrm{ab}$ & $48.83 \mathrm{ab}$ & $14.70 \mathrm{ab}$ & $17.73 \mathrm{ab}$ \\
\hline 5 Gy & $24.00 \mathrm{a}$ & $25.33 \mathrm{a}$ & $4.15 \mathrm{bc}$ & $3.82 \mathrm{ab}$ & $19.32 \mathrm{a}$ & $18.67 \mathrm{a}$ & $36.30 \quad \mathrm{a}$ & $49.13 \mathrm{a}$ & $15.46 \quad \mathrm{a}$ & $17.98 \mathrm{a}$ \\
\hline 10 Gy & $21.66 \mathrm{~b}$ & $22.55 \mathrm{~b}$ & $4.13 b c$ & $3.93 \mathrm{ab}$ & $18.33 \mathrm{abc}$ & $17.70 \mathrm{ab}$ & $33.73 \mathrm{abc}$ & $43.35 \mathrm{c}$ & $14.08 \mathrm{abc}$ & $17.73 \mathrm{ab}$ \\
\hline 15 Gy & $21.33 \mathrm{bc}$ & $22.66 \mathrm{~b}$ & $4.20 \mathrm{~b}$ & $4.11 \mathrm{a}$ & $19.00 \mathrm{ab}$ & $18.49 \mathrm{a}$ & $34.00 \mathrm{abc}$ & $44.78 \mathrm{bc}$ & $13.72 \mathrm{abc}$ & $17.39 \mathrm{ab}$ \\
\hline 20 Gy & $20.66 \mathrm{bc}$ & $22.99 \mathrm{~b}$ & 4. $63 \mathrm{a}$ & $4.17 \mathrm{a}$ & $18.13 \mathrm{abc}$ & $15.45 \mathrm{c}$ & $32.70 \mathrm{bcd}$ & $38.86 \mathrm{~d}$ & $12.21 \mathrm{cde}$ & $16.19 \mathrm{ab}$ \\
\hline 25 Gy & $17.33 \mathrm{~d}$ & $20.99 \mathrm{bc}$ & $4.26 \mathrm{ab}$ & $4.13 \mathrm{a}$ & $16.66 \mathrm{~cd}$ & $15.73 \mathrm{c}$ & $30.55 \mathrm{~cd}$ & $38.60 \mathrm{~d}$ & $10.63 \mathrm{e}$ & $15.60 \mathrm{~b}$ \\
\hline 30 Gy & $19.81 \mathrm{c}$ & $22.22 b c$ & $4.04 \mathrm{bc}$ & $3.85 \mathrm{ab}$ & $17.53 \mathrm{bcd}$ & $16.41 \mathrm{bc}$ & $32.70 \mathrm{bcd}$ & $37.36 \mathrm{~d}$ & $14.77 \mathrm{ab}$ & $15.60 \mathrm{~b}$ \\
\hline 35 Gy & $20.44 b c$ & $18.10 \mathrm{~d}$ & 4. $01 \mathrm{bc}$ & $3.82 \mathrm{ab}$ & $16.04 \mathrm{de}$ & $13.26 \mathrm{~d}$ & $30.08 \mathrm{~d}$ & $36.96 \mathrm{~d}$ & $11.64 \mathrm{de}$ & $15.09 \mathrm{~b}$ \\
\hline 40 Gy & $16.66 \mathrm{~d}$ & $17.96 \mathrm{~d}$ & $3.76 \mathrm{c}$ & $3.11 \mathrm{~b}$ & 14.86 & $12.60 \mathrm{~d}$ & $21.59 \mathrm{e}$ & $31.92 \mathrm{f}$ & 6.59 & $11.89 \mathrm{c}$ \\
\hline
\end{tabular}




\subsection{Plant abnormalities of $\boldsymbol{H}$. bracteatum $\mathrm{L}$}

3.2.1. Plant abnormalities of $\boldsymbol{H}$. bracteatum $\mathrm{L}$. as affected by different doses of gamma rays on inflorescence color and variegated plant in $\mathrm{M} 1$ and $\mathrm{M} 2$ generations.

Data in Table (2) and Fig. (1) show the abnormalities of leaves and flowers of H.bracteatum L. plant in response to gamma radiation treatments at the doses 5-40 Gy. The abnormalities of H.bracteamum L. resulted as variegated leaf and flower color in M1 and M2 generations. The number of abnormal leaves and flowers increased with the low doses of gamma rays (5, 15 and $20 \mathrm{~Gy})$.

Table 2: The abnormal phenotypes of M1 and M2 generations caused by different doses of gamma rays treatments.

\begin{tabular}{llllll}
\hline No. & Dose & Abnormal phenotype & No. & Dose & Abnormal phenotype \\
\hline $\mathbf{1}$ & Control & Normal plant (original color) (a) & $\mathbf{3}$ & $\mathbf{2 0}$ & Flower color (c) \\
$\mathbf{2}$ & $\mathbf{1 5 ~ G}$ & Flower color and variegated plant & $\mathbf{4}$ & $\mathbf{2 5}$ & Flower color (d, e, f, g) \\
& & Flower (b, h) & & \\
\hline
\end{tabular}
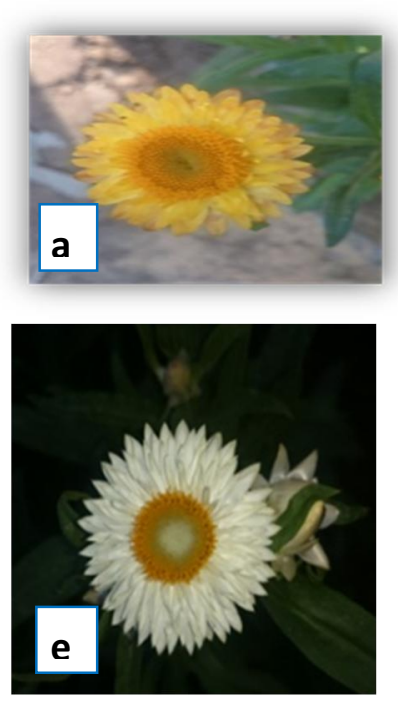
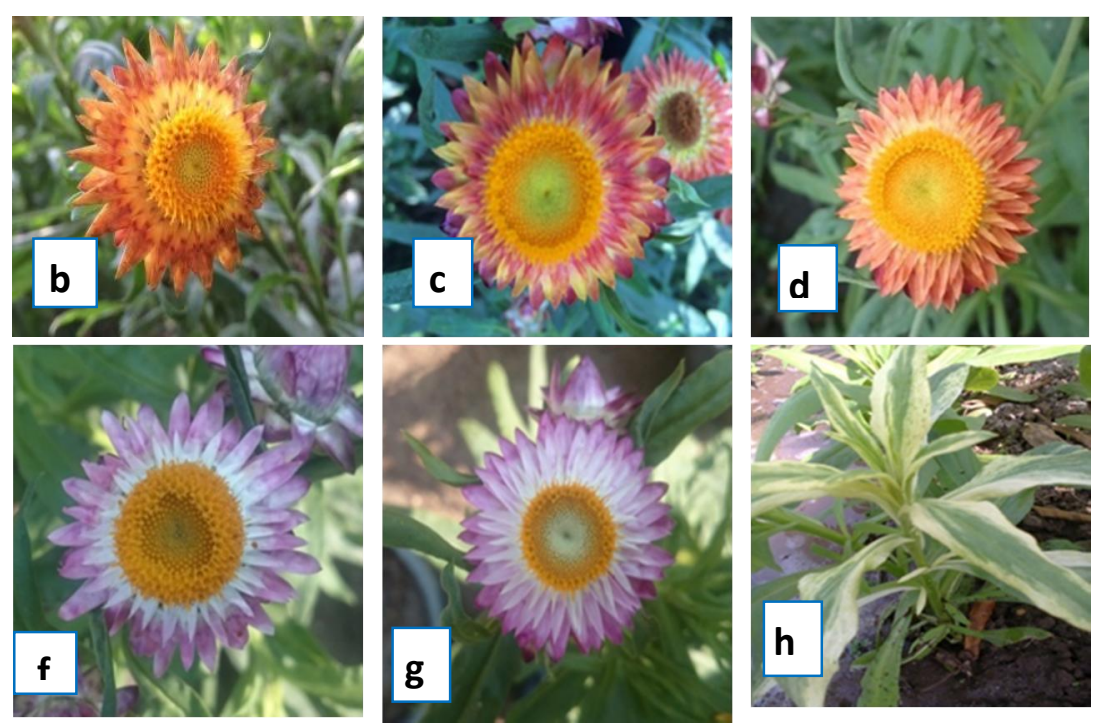

Fig. 1: Showing the plant abnormalities of $H$. bracteatum L. as affected by different doses of gamma rays on inflorescence color and variegated plant in M1 and M2 generations. (a, in M1 and M2, (original color) yellow color of control plants. (b, in M2, yellow color inside and orange color outside of petals as a resulted of $15 \mathrm{~Gy}$. (c, in M1 and M2, deep rose or lightly red color inside and orange color outside of petals as a resulted of $20 \mathrm{~Gy}$. (d, in M1 and M2, orange color as a resulted of $25 \mathrm{~Gy}$. (e, in M1 and M2, white color as a resulted of $25 \mathrm{~Gy}$. (f, in M2, white color inside and lightly violet color outside of petals as a resulted of $25 \mathrm{~Gy}$. (g, in M2, lightly violet color or purple white as a resulted of $25 \mathrm{~Gy}$. (h, in $\mathrm{M} 1$, variegated plant as a resulted of $15 \mathrm{~Gy}$.

The obtained mutants in flowers color (b, c, d, e, f, g) may be due to a mutation in the biosynthetic pathway of structural or regulatory genes may cause a change in flower color, Nakatsuka et al.(2005). When the blockage occurs at the early stages of anthocyanin synthesis, white flowers will result, while a blockage at later stages leads to different flower colors due to the accumulation of particular anthocyanin, gene and /or plastid changes, Wi et al. (2007). Also, in this regard, Rashid et al. (2013) on Zingiber officinale treated with gamma ray found that gamma ray caused some abnormalities as; dwarf plants, plant with crooked stems and corrugated leaves. Singh and Sisodia (2015) treated seven gladiolus varieties with gamma doses, i.e., 1.5, 2.5, 2.5, 3.5, 4.5 or $5.5 \mathrm{Krad}$. They observed various morphological changes on the plants and flowers at 2.5 and $4.5 \mathrm{Krad}$ gamma irradiation doses.

\subsubsection{Effect of gamma on anatomical structure of leaves}

a. No. of xylem rows

Data in Table 3 and (Fig. 2) indicated that the gamma rays treatment at the dose of 15 Gy increased the No. of xylem rows of leaf, and gave the maximum value (15 rows), as compared with the 
other gamma radiation treatments and the control gave (12 rows). On the contrary, the lowest value was (5 rows) obtained by treated plants with $25 \mathrm{~Gy}$, as compared with the control.

\section{b. No. of xylem vessels}

Obtained results in Table 3and (Fig. 2) showed that all treatments of gamma radiation decreased the number of xylem vessels (73, 43, 33, 42 and 77), as compared with the control (80).

\section{c. Thickness of lamina $(\mu \mathrm{m})$}

It was revealed from the data in Table 3 and (Fig. 2) that, all treatments of gamma radiation increased the thickness of lamina compared to the control $(115.76 \mu \mathrm{m})$, plants irradiation with gamma at 15 Gy gave the highest value $(151.5 \mu \mathrm{m})$.

\section{d. Thickness of midveine ( $\mu \mathrm{m})$}

As shown in Table 3 and (Fig. 2) concerning the effect of gamma radiation treatments on thickness of midveine, the data indicated that, irradiation with gamma at $15 \mathrm{~Gy}$ gave the highest value (504.16 $\mu \mathrm{m})$ as compared with the control $(493.58 \mu \mathrm{m})$.

Table 3: Effect of gamma radiation treatments on number of xylem rows, number of xylem vessels, thickness of lamina $(\mu \mathrm{m})$, thickness of midveine $(\mu \mathrm{m})$, length of vascular bundle $(\mu \mathrm{m})$ and width of vascular bundle $(\mu \mathrm{m})$ of $H$. bracteatum L. plant

\begin{tabular}{|c|c|c|c|c|c|c|}
\hline \multirow[b]{2}{*}{ Treatment } & \multirow[b]{2}{*}{$\begin{array}{l}\text { No. of } \\
\text { xylem } \\
\text { rows }\end{array}$} & \multirow[b]{2}{*}{$\begin{array}{l}\text { No. of } \\
\text { xylem } \\
\text { vessels }\end{array}$} & \multirow[b]{2}{*}{$\begin{array}{c}\text { Thickness of } \\
\text { lamina (blade) } \\
(\mu \mathrm{m})\end{array}$} & \multirow[b]{2}{*}{$\begin{array}{c}\text { Thickness } \\
\text { of midveine } \\
(\mu \mathrm{m})\end{array}$} & \multicolumn{2}{|c|}{ Dimension of bundle } \\
\hline & & & & & $\begin{array}{l}\text { Length of } \\
\text { vascular } \\
\text { bundle }(\mu \mathrm{m})\end{array}$ & $\begin{array}{c}\text { Width of } \\
\text { vascular } \\
\text { bundle } \\
(\mu \mathrm{m})\end{array}$ \\
\hline Control & 12 & 80 & 115.76 & 493.58 & 236.90 & 194.86 \\
\hline 15 Gy & 15 & 73 & 151.50 & 504.16 & 237.70 & 260.68 \\
\hline $20 \mathrm{~Gy}$ & 8 & 43 & 117.04 & 436.08 & 186.32 & 196.20 \\
\hline 25 Gy & 5 & 33 & 134.50 & 290.92 & 141.60 & 149.24 \\
\hline 30 Gy & 7 & 42 & 141.94 & 489.44 & 186.32 & 180.36 \\
\hline 35 Gy & 12 & 77 & 138.02 & 495.34 & 196.26 & 204.34 \\
\hline
\end{tabular}

Gy $=$ Gray $\mu \mathrm{m}=$ Micrometer

\section{e. Dimension of vascular bundle $(\mu \mathrm{m})$}

Data presented in Table 3 and (Fig. 2) showed that, the effect of gamma doses on the length and width of vascular bundle $(\mu \mathrm{m})$ of leaf, at $15 \mathrm{~Gy}$ gave the maximum length of vascular bundle $(237.70$ $\mu \mathrm{m})$, while irradiation seeds with gamma at 25 Gy gave the lowest value of length of vascular (141.6 $\mu \mathrm{m})$ as compared with the control plant (236.9). While, the previous mentioned treatments recorded decrease $(149.24 \mu \mathrm{m}$ and $180.36 \mu \mathrm{m})$ in width of bundle compared with control (194.86).

The wider width of bundle was obtained from treated seeds with gamma radiation at 15 Gy (260.68), while the lowest wider of bundle was obtained from treated seeds with gamma radiation at 25 Gy $(149.24 \mu \mathrm{m})$. The highest values in dimension of bundle were obtained from treated seeds with gamma radiation at $15 \mathrm{~Gy}$.The values reached for the previous mentioned treatment $(237.70 \mu \mathrm{m}$ length, $260.68 \mu \mathrm{m}$ width) in comparison with other treatments.

In this regard, Khalifa (2016) on Spathiphyllum wallisii using gamma rays by doses $(0.5,4$ and 8 $\mathrm{Kr}$, the results revealed that $4 \mathrm{Kr}$ gave the largest of the thickest midrib followed by $0.5 \mathrm{Kr}$. Whereas, the dose $8 \mathrm{Kr}$ gave the smallest diameter as compared with the control; Abou Leila et al. (2012) exposed gerbera offshoots with gamma rays $(100,150$ and $250 \mathrm{rad})$. They found that single treatments with gamma rays were efficient on leaf area and anatomical structure.

Also, Esmail (2014) investigated the effect of gamma rays on anatomical structure of leaves Dracaena surculosa and Beaucarnea recurvate plants. He observed change in anatomical structure of leaves. Also, the results showed that the largest of diameter of vascular bundles were recorded as a result of 10 Gy treatment. 

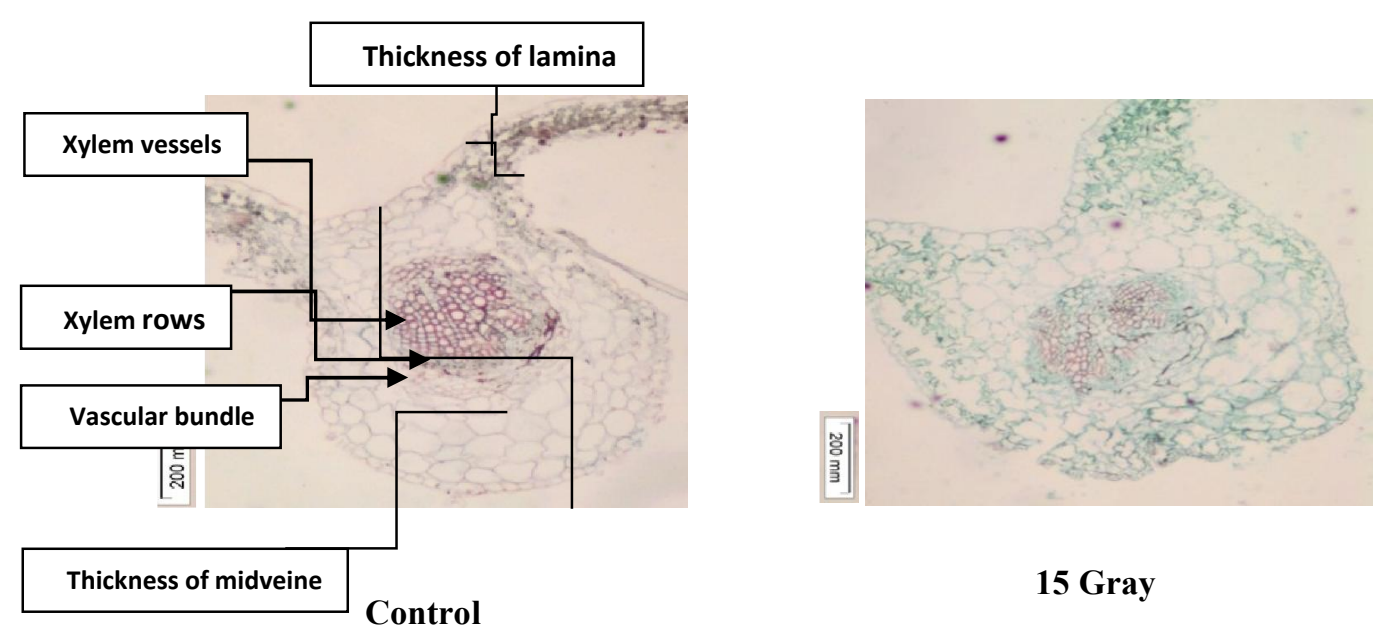

15 Gray

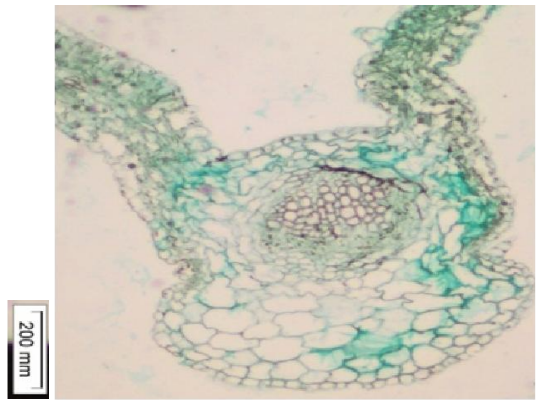

20 Gray

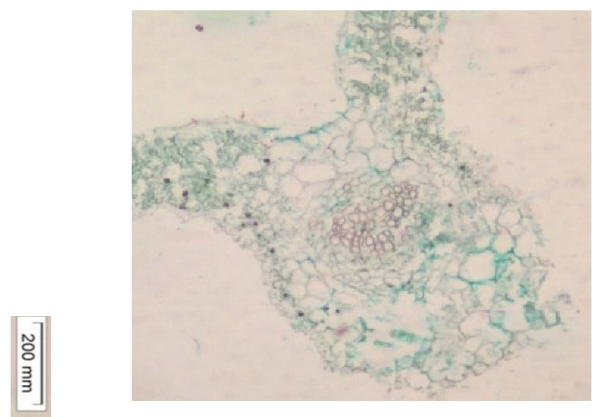

30 Gray

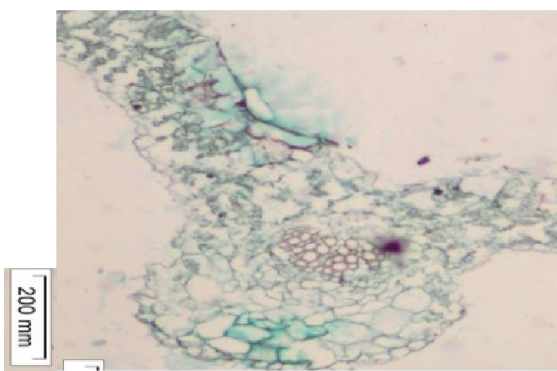

25 Gray

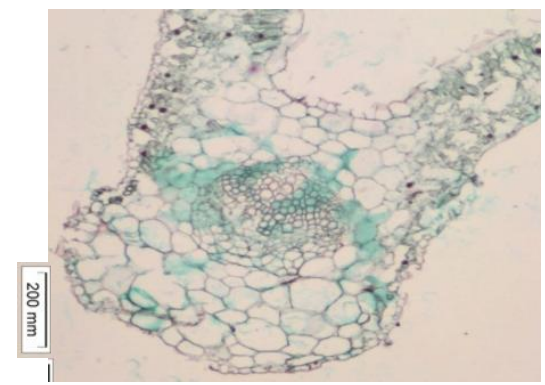

35 Gray

Fig. 2: Anatomical structure of leaves in $H$. bracteatum as affected by gamma radiation doses compared the control, (Transverse section through the leaves of the third developed leaf from the third branch of the upper part of the main stem of the plant $(x=80))$.

\subsubsection{Effect of gamma on anatomical structure of flowers} a. Flowering bud diameter (FBD)

Data in Table (4) and Fig. (3) revealed that, irradiation with gamma at $15 \mathrm{~Gy}$ increased flowering bud diameter as compared with the control plants. Maximum value of bud diameter $(6525 \mu \mathrm{m})$ resulted with $35 \mathrm{~Gy}$ at the rate of $(38.09 \%)$ as compared with the untreated plants. $(4725 \mu \mathrm{m})$, followed by irradiation with gamma at 15 Gy arrived to $(22.22 \%)$ compared to with the control.

\section{b. Receptacle diameter $(\mu \mathrm{m})$}

The results pretsnds in Table (4 and Fig.3) revealed that, treatment 35 Gy of gamma radiation gave the highest receptacle diameter $(3750 \mu \mathrm{m})$, the increment was $(66.66 \%)$, while treatment with gamma radiation at $25 \mathrm{~Gy}$ gave the lowest value of receptacle diameter $(1500 \mu \mathrm{m})$ with rate reached to $(13.33 \%)$ compared with the control plants $(2250 \mu \mathrm{m})$. 
Table 4: Effect of gamma radiation treatments on flowering bud diameter (FBD) $(\mu \mathrm{m})$ and receptacle diameter $(\mu \mathrm{m})$ of Helichrysum bracteatum L. plant, during the M3 (2016/17).

\begin{tabular}{ccc}
\hline Treatments & Flowering bud diameter (FBD) $(\boldsymbol{\mu m})$ & Receptacle diameter $(\boldsymbol{\mu m})$ \\
\hline Control & 4725 & 2250 \\
$\mathbf{1 5} \mathbf{~ G y}$ & 5775 & 3600 \\
$\mathbf{2 0} \mathbf{~ G y}$ & 4800 & 1950 \\
$\mathbf{2 5} \mathbf{~ G y}$ & 4050 & 1500 \\
$\mathbf{3 5} \mathbf{~ G y}$ & 6525 & 3750 \\
\hline
\end{tabular}

Gy=Gray $\mu \mathrm{m}=$ Micrometer

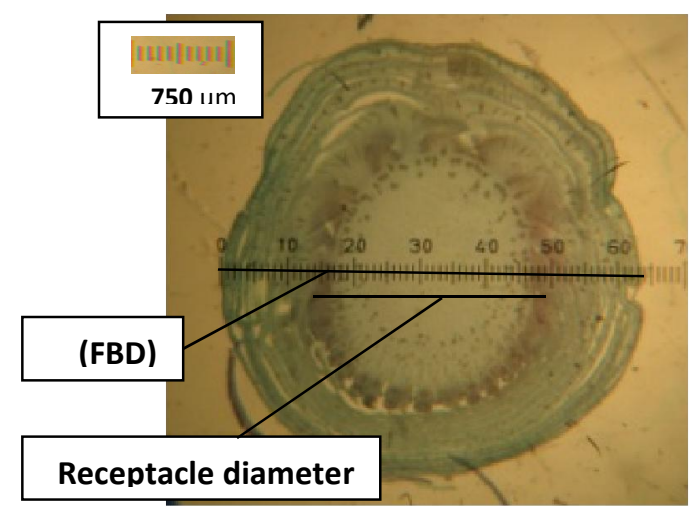

Control

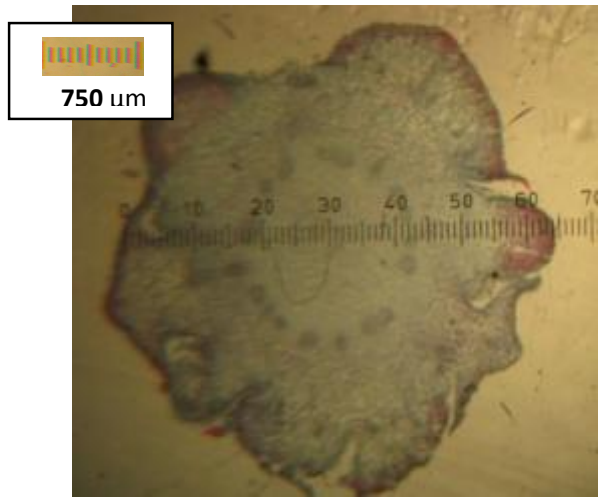

20 Gray

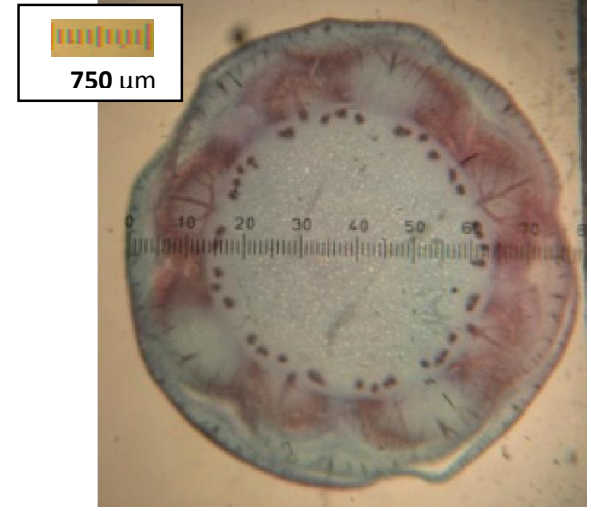

15 Gray

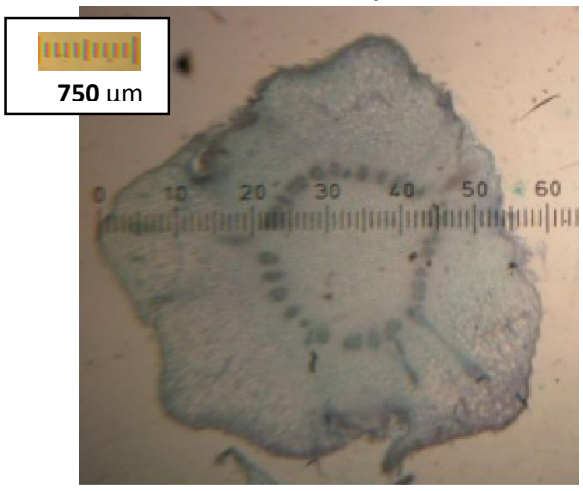

25 Gray

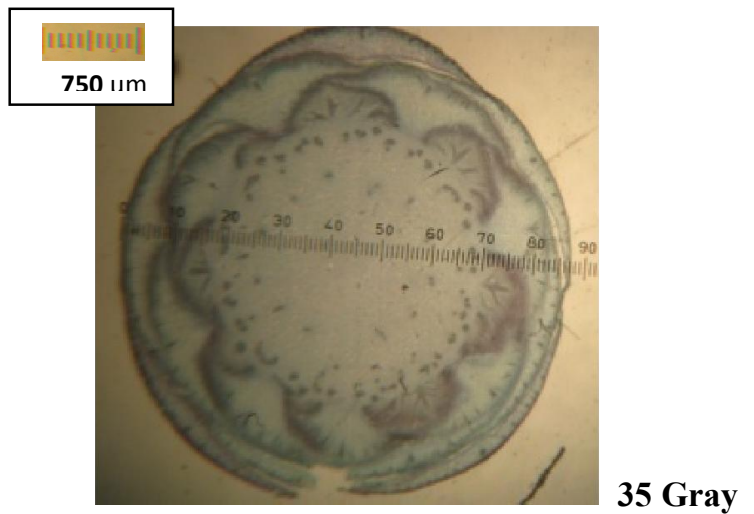

FBD $=$ Flowering bud diameter

Fig. 4: Anatomical structure of flowers in $H$. bracteatum as affected by gamma radiation doses compared the control, (Transverse section through the flowering bud $(\mathrm{x}=40)$ ). 


\section{References}

Abou Leila, B., A.E. Awad, T.A.E. Tayeb, I.E. Habba, and S.A. Metwally, 2012. Anatomical aspects of Gerbera leaves under the effect of progestrone and irradiation. Journal of Applied Sciences Research, 8(12):5903-5912.

Akhtar, A., M. Ansari, Hisamuddin, 2012. Cytological effect of ethyl methane sulphonate and sodium azide in Linum usitatissimum L. International Journal of Plant, Animal and Environmental Sciences, 2(1):70-75.

Aruna S.D. and S. Rao, 2014. Effect of gamma radiation on germination and physiological aspects of pigeon pea (Cajanus cajan (L.) millsp). seedlings. International Journal of Research in Applied, Natural and Social Sciences (Impact: IJRANSS), 2(6):47-52.

Chandrashekar, K.R., H.M. Somashekarappa, and J. Souframanien, 2013. Effect of gamma irradiation on germination, growth, and biochemical parameters of Terminalia arjuna Roxb. Radiation Protection and Environment, 36(1):38-44.

Dhivya, M., S. Balakrishanan, and S.H. Juliet, 2015. Radiation induced variability in crossandra (Crossandra infundibuliformis (L.) Nees). International Journal of Agricultural Science and Research, 5(3):267-272.

Duncan, D.B., 1980. Multiple range and multiple f effect of gamma radiation on growth and flowering of Test. Biometrics, 11:1-42.

El-Khateeb, M.A., K.E.A. Abdel-Ati, and M.A.S. Khalifa, 2016. Effect of gamma irradiation on growth characteristics, morphological variations, pigments and molecular aspects of Philodendron scandens plant. Middle East Journal of Agriculture Research, 5(1):6-13.

El-Sherif, F., S. Khattab, E. Goniam, N. Salem, and K. Radwan, 2011. Effect of gamma irradiation on enhancement of some economic traits and molecular changes in Hibiscus sabdariffa. Life Sci. J., 8(3):220-229.

Esmail, S.E.A., 2014. Effect of some growth regulators and irradiation on propagation and anatomical structure of Deracaena surculosa Lindl. and Beaucarnea recurvata Lem. plants by using tissue culture technique. Ph.D. Thesis, Cairo University. Faculty of Agriculture. Department Of Ornamental Horticulture, 192 P.

Jan, S., T. Parween, R. Hameed, T.O. Siddiqi, and Mahmooduzzafar, 2013. Effects of presowing gamma irradiation on the photosynthetic pigments, sugar content and carbon gain of Cullen corylifolium (L.) Medik. Chilean Journal of Agricultural Research, 73(4):345-350.

Kainthura, P. and R. Srivastava, 2015. Induction of genetic variability and isolation of mutants in Tuberose (Polianthes tuberosa L). Tropical Agricultural Research, 26(4):721-732.

Kapadiya, D.B., S.L. Chawla, A.I. Patel, and T.R. Ahlawat, 2014. Exploitation of variability through mutagenesis in chrysanthemum (Chrysanthemum morifolium Ramat.) var. maghi. the BioScan (An International Quarterly Journal of Life Science), 9(4):1799-1804.

Kapoor, M., A. Kumar, and S. Lal, 2015. Induction of genetic variability through gamma irradiation in mini marguerite (Chrysanthemum paludosum Poir.) and their RAPD-based genetic relationship. Journal of Horticulture, 72(1):77-83.

Khalifa, 2016. Response of Spathiphyllum wallisii Regel. and Philodendron scandes C. Koch and H. Sello plants to gamma irradiation. MSc. Thesis, Ornamental Horticultural Department, Faculty of Agriculture, Cairo University, 143.

Kumari, K., K.K. Dhatt, and M. Kapoor, 2013. Induced mutagenesis in Chrysanthemum morifolium variety 'Otome pink' through gamma irradiation. The BioScan (An International Quarterly Journal of Life Science), 8(4):1489-1492.

Nassar, M.A. and K.F. El-Sahar, 1998. Plant Microtechnique. Academic Bookshop, Egypt, (In Arabic), 224.

Nakatsuka, T., M. Nishihara, K. Mishiba, and S. Yamamura, 2005. Two different mutations are involved in the formation of white-flowered gentian plants, Plant Science, 169(5): 949-958

Nishikawa, K., H. Ito, T. Awano, M. Hosokawa, and S. Yazawa, 2008. Characteristic thickened cell walls of the bracts of the 'eternal flower' Helichrysum bracteatum". Annals of Botany, 102(1):3137. 
Oates, K.M., D.H. Touchell, and T.G. Ranney, 2013. Induced variation in Tetraploid Rudbeckia subtomentosa 'Henry Eilers' regenerated from gamma-irradiated callus. Hortscience, 48(7):831834.

Omar, Y.A., 2016. Effect of physical and chemical mutagens on Lathyrus odoratus. Ph.D. Thesis, Zagazig Faculty of Agriculture, University, Department of Horticulture, 154.

Patil, S.D., 2014. Induction of mutation in commercial varieties of gladiolus using physical mutagen CO-60 gamma rays. Int. J. Advanced. Res. Biol. Sci., 1(6):15-20.

Sass, J.F., 1951. Botanical Microtechinque. IOWA Stale college prese, Ame Iowa, 228.

Sharman, K.V., M. Sedgley, and D. Aspinall, 1989a. Production of the Australian native daisies (Helichrysum roseum and Helichrysum bracteatum) for the cut flower market. Aust. J. Exper. Agric., 29:445-453.

Sharman, K.V., M. Sedgley, and D. Aspinall, 1989b. Effects of photoperiod, temperature and plant age in floral initiation and inflorescence quality in the Australian native daisies Helichrysum roseum and Helichrysum bracteatum in relation to cut flower production. J.Hort. Sci., 64:351-359.

Singh, B., 2014. Effect of gamma rays on vegetative and flowering parameters of gerbera (Gerbera jamesonii Bolus Ex Hooker F.). HortFlora Research Spectrum, 3(3):267-270.

Singh, A. and A. Sisodia, 2015. Effect of gamma irradiation on morphological changes, flowering and induced mutants in gladiolus. Indian Journal of Horticulture, 72(1):84-87.

Sinhamahapatra, S.P. and S.C. Rakshit, 1990. Response to selection for plant height in X-ray treated population of jute (Corchorus caspularis L.) cv. JRC 212. Euphytica, 51:95-99.

Snedecor, G.W. and W.G. Cochran, 1980. Statistical Methods. 7th ed., Iowa Stat. Univ., Press, Ames, Iowa, USA.

Telem, R.S., R. Sadhukhan, N. Mandal, H.K. Sarkar, and S.H. Andwani, 2015. Gamma rays induced mutagenesis for identification of new variants via RAPD markers in chrysanthemum (Chrysanthemum morifolium Ramat.). Journal of Cell and Tissue Research, 15(3):5289-5294.

Wi, S.G., B.Y. Chung, J.S. Kim, J.H. Kim, M.H. Baek, J.W. Lee, and Y.S. Kim, 2007. Effects of gamma irradiation on morphological changes and biological responses in plants. Micron, 38(6):553-564.

Upadhyay, A., 2014. Induction of mutation in commercial varieties of gladiolus using physical mutagen $\mathrm{Co}^{-60}$ gamma rays. Intern. J. of Advanced Research in Biosciences, 1(6):79-86.

Yalindua, A., S.S. Asep and H.M.H. Bintoro, 2014. The aplication of mutation induction by gamma irradiation on cultivars yam (Dioscorea alata L.) from banggai islands, Indonesia. International Journal of Agronomy and Agricultural Research, 5(2):46-54. 